\title{
Mortality and morbidity in a pulp and a paper mill in the United States: a ten-year follow-up*
}

\author{
B. G. FERRIS, JR., S. PULEO, AND H. Y. CHEN \\ From the Kresge Center for Environmental Health, Harvard School of Public Health, 665 Huntington \\ Avenue, Boston, Massachusetts 02115, USA
}

\begin{abstract}
Two hundred and seventy-one men seen in 1963, who worked in a pulp and a paper mill, were followed up ten years later, in 1973. Death certificates were obtained for those who died. There did not appear to be any increased mortality in the group, nor was there any increased specific cause of death. A morbidity study of 200 men seen at both times did not show any differences in respiratory symptoms or prevalence of chronic non-specific respiratory disease. Analysis of pulmonary function showed little, if any, difference between groups. Analysis of retired, deceased, and still-working categories did suggest that exposures to $\mathrm{Cl}_{2}$ or $\mathrm{SO}_{2}$ might have a slight adverse effect on pulmonary function.
\end{abstract}

In 1963 we made a cross-sectional study on a group of men who had been working in a pulp and a paper mill in Berlin, New Hampshire, USA (Ferris et al., 1967). Our purpose at that time was to see whether the exposure at work had an effect on chronic non-specific respiratory disease or pulmonary function. That study showed that the workers had less chronic non-specific respiratory disease than the general population, but the older men who had been exposed to chlorine and who were cigarette smokers had slightly lower expiratory flow rates at 50,25 , and $12.5 \%$ of vital capacity than the men who had not been exposed to chlorine.

In 1973 we restudied that cohort to determine whether they had a higher mortality than expected, or had developed respiratory disease.

\section{Methods}

\section{PLANT PROCESSES}

The pulp mill complex contained two chemical pulp mills-one a Kraft mill and the second a sulphite mill and, in addition, a chlorine plant. The sulphite mill and chlorine plant were phased out after 1963, and the Kraft process increased. In both mills, wood chips are introduced into large

*Supported in part by Grants ES 00002 and ES 00868 from the US Public Health Service

Received for publication 31 March 1978

Accepted for publication 16 May 1978 digesters or batch pressure cookers. Cooking liquor is added and the batch is cooked under raised temperature and pressure. The cooking liquor in the Kraft process contains sodium sulphide, hydroxide, sulphite, and carbonate. In the sulphite phase the digester load is dropped or blown into pits. The cooking liquor is drained for recovery and re-use and the pulp undergoes final processing. The two processes result in exposure of personnel to sulphur dioxide, hydrogen sulphide, and some organic sulphides including mercaptans.

In the final processing, the pulp is washed and bleached. The first stage of bleaching is carried out with chlorine or chlorine dioxide. This plant formerly manufactured its own chlorine.

In paper-making the pulp is resuspended in water and various additives and fillers are added to the mixture which is blended together. The type of additives and filler varies with the type of paper product to be manufactured. The slurry of the mixture is then poured out on a moving screen that allows the water to drain off, leaving behind a mat of the blend which is then run around steam-heated colanders to dry it into the paper product. Exposures to the workers during usual paper-making are minimal.

\section{MORTALITY STUDY}

The cohort was surveyed in the summer of 1973. Those who had died were identified and their death certificate was sought to determine cause 
of death. Person-years at risk were calculated for this population by assigning the full time period $(10 \mathrm{yr})$ to the survivors; those who died contributed a year for each year completed and a half-year for the year in which death occurred.

Expected deaths were calculated, based on the age distribution of the cohort population as of 1968 , from the age-specific death rates for white males for the same time period, as the cohort consisted of white males only.

\section{MORBIDITY STUDY}

Those who had moved were identified and their status determined. Those who remained, and were willing, were surveyed by means of a standard questionnaire on respiratory symptoms which was the same as that used in the initial survey. Pulmonary function was assessed on a Stead Wells spirometer, either a table model or survey type, at a paper speed of $3.2 \mathrm{~cm} / \mathrm{s}$. The various spirometers had been calibrated against each other during use, and had been found to agree within $1 \%$. The table model had been used in the earlier survey. In general, five trials were made and the average of the last three curves was used to obtain the forced vital capacity (FVC), and forced expiratory volume in one second $\left(F E V_{1.0}\right)$. In general, these values were also the three best. These values were corrected to body temperature and pressure-saturated (BTPS). In addition, from these spirograms the flows at $75,50,25$, and $12.5 \%$ of vital capacity were measured by means of a clear plastic template that had a fan-like arrangement of lines. Fitting the appropriate line tangentially at the specified fraction of vital capacity enabled the flow to be read. The average of the values from the last three curves was used and expressed at BTPS.

Peak expiratory flows were measured by means of Wright peak flow meters that had been calibrated against a standard orifice meter under normal working conditions. Each value was corrected according to the appropriate calibration curve. The average of the last three of five trials was used. These values were at ambient temperature and pressure-saturated (ATPS).

All respiratory measurements were made with the subject seated but with free body movement. Nose clips were not used.

Height was measured to the nearest $0.5 \mathrm{~cm}$ by means of a right angle with the subject in stockinged feet standing straight against a tape on a wall. Age was that at the last birthday.

Subjects have been classified according to their jobs in 1963. Interim occupational histories were used to assess changes in job and possibly in exposure. No additional air samples were obtained in the work areas since those taken in 1963 (Ferris et al., 1967). Exposure to $\mathrm{SO}_{2}$ had probably decreased, since the sulphite process had been terminated in about 1963 . Thus, we are primarily concerned with possible chronic effects of the earlier exposure rather than with acute responses to present exposure.

\section{Results}

In 1963, 271 subjects were seen. The disposition of that sample when followed up in 1973 is shown in Table 1. Of the 1963 sample, 200 were seen also in 1973; thus, the morbidity study deals with that group. Death certificates were available for all except two of those subjects who had died.

ESTIMATED EXPOSURES (1963)

Exposure was estimated from the 1963 data (Ferris et al.) (Table 2). The sulphite operation had been discontinued after 1963, but the Kraft process had been greatly expanded. The cell house or chemical plant where $\mathrm{Cl}_{2}$ was produced electrolytically had also been shut down, but the bleaching department using $\mathrm{Cl}_{2}$ or $\mathrm{ClO}_{2}$ had been expanded.

Table 1 Distribution of 1963 sample in 1973 by occupational exposures (1963)

\begin{tabular}{lcccc}
\hline Status in 1973 & \multicolumn{5}{c}{ Number of subjects exposed in 1963} \\
\cline { 2 - 5 } & $C l_{2}$ & $S O_{2}$ & Paper & Total \\
\hline Seen 1963 & 71 & 78 & 122 & 271 \\
Seen 1973 & $50^{*}$ & 61 & 91 & $202^{*}$ \\
Deceased & 9 & 8 & 16 & 33 \\
IIl & - & 1 & -5 & 1 \\
Moved & 5 & -3 & 5 & 10 \\
Refused & 3 & 3 & 4 & 10 \\
Missed & 3 & 3 & 4 & 10 \\
Subjects who did not match & & & 2 & 5 \\
$\quad$ 1963 sample & 1 & 2 & 31 & 78 \\
Retired & 26 & 21 & & \\
\hline
\end{tabular}

* Two ill in 1963 and not studied at that time; total used for analysis is therefore 200 .

Table 2 Estimated previous exposure levels in the pulp mill (ppm)

\begin{tabular}{|c|c|c|c|c|c|c|}
\hline \multirow{3}{*}{$\begin{array}{l}\text { Irritant } \\
\text { gas }\end{array}$} & \multicolumn{6}{|c|}{ Exposure levels per year } \\
\hline & \multicolumn{2}{|l|}{1958} & \multicolumn{2}{|l|}{1962} & \multicolumn{2}{|l|}{1963} \\
\hline & Mean & $\operatorname{Max}$ & Mean & $\operatorname{Max}$ & Mean & $\operatorname{Max}$ \\
\hline $\begin{array}{l}\mathrm{Cl}_{2} \\
\mathrm{SO}_{2} \\
\mathrm{H}_{2} \mathrm{~S}\end{array}$ & $\begin{array}{l}7 \cdot 4 \\
-\end{array}$ & $\begin{array}{l}64 \\
33 \\
-\end{array}$ & $\begin{array}{l}\text { Trace* } \\
4 \\
0\end{array}$ & $\begin{array}{l}\text { Trace } \\
8 \\
0\end{array}$ & $\begin{aligned}< & 0.001 \\
& 2 \\
< & 4\end{aligned}$ & $\begin{aligned}< & 0.001 \\
& 6 \\
< & 4\end{aligned}$ \\
\hline
\end{tabular}

*Trace $<0.0005$.

Taken from Table 3, Ferris et al., 1967. 
Table 3 Mortality rates by exposure category in a pulp and paper mill, Berlin, New Hampshire, USA, 1963-1964

\begin{tabular}{|c|c|c|c|c|c|}
\hline $\begin{array}{l}\text { Exposure } \\
\text { category (1963) }\end{array}$ & $\begin{array}{l}\text { Person-years } \\
\text { at risk }(P Y R)\end{array}$ & $\begin{array}{l}\text { Observed } \\
\text { deaths (no.) }\end{array}$ & $\begin{array}{l}\text { Deaths per } \\
1000 \text { PYR }\end{array}$ & $\begin{array}{l}\text { Expected* } \\
\text { deaths (no.) }\end{array}$ & Standardised Mortality Ratio \\
\hline $\begin{array}{l}\mathrm{Cl}_{2} \\
\mathrm{SO}_{2} \\
\text { Paper }\end{array}$ & $\begin{array}{r}676 \\
753 \\
1165\end{array}$ & $\begin{array}{r}9 \\
8 \\
16\end{array}$ & $\begin{array}{l}13.3 \\
10.6 \\
13.7\end{array}$ & $\begin{array}{l}9 \cdot 06 \\
7 \cdot 22 \\
9 \cdot 85\end{array}$ & $\begin{array}{l}0.99 \\
1.11 \\
1.62\end{array}$ \\
\hline Total & 2594 & 33 & $12 \cdot 7$ & $26 \cdot 13$ & $1 \cdot 26$ \\
\hline
\end{tabular}

*Calculated from age-specific death rates for white males. US populations excluding Hawaii and Alaska (US Bureau of the Census, 1971) using age distribution for each exposure category.

Table 4 Cause of death by exposure category (1963)

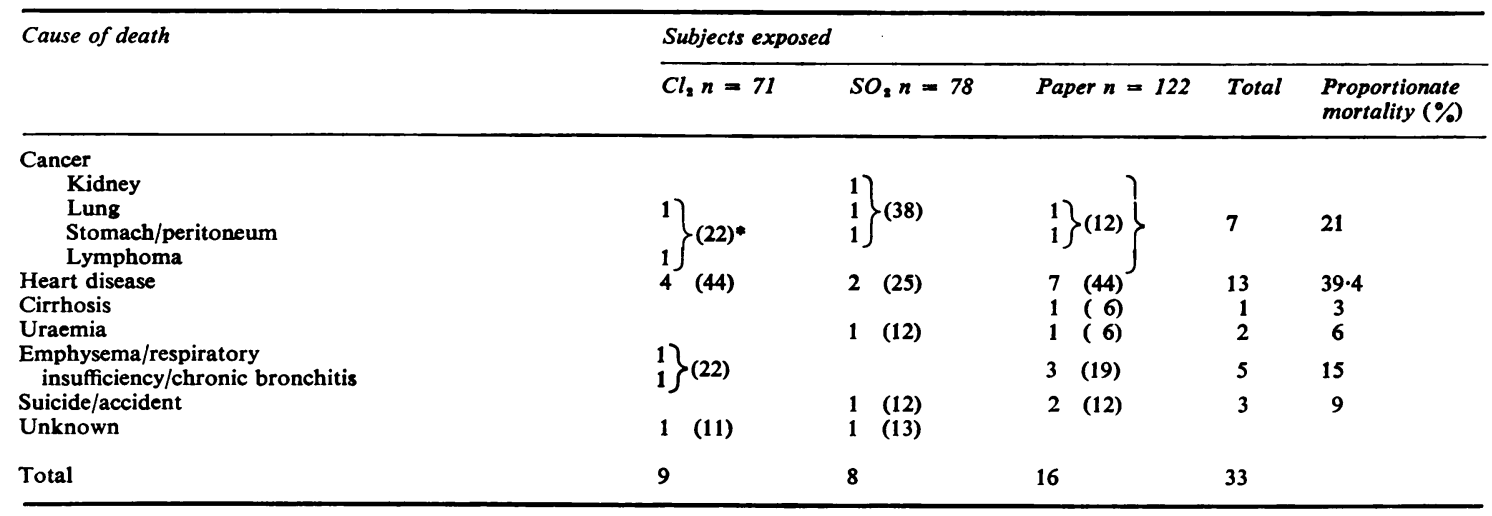

* Percentages in parentheses.

MORTALITY STUDY

The mortality rates by exposure category are given in Table 3 and are based on person-years at risk for this 10-year period, 1963-1973. Rates for the $\mathrm{SO}_{2}$-exposed group are slightly lower than for those exposed to $\mathrm{Cl}_{2}$ or paper, but are not significantly different, because of the small numbers involved.

The expected number of deaths for each group was calculated from the contiguous US white male population (US Bureau of the Census, 1971), taking into account the age groups in each category. The observed number of deaths for chlorine and $\mathrm{SO}_{2}$ workers does not differ markedly from the expected number, whereas that fo: the paper workers was greater than expected (SMR 1.62). None of these differences was significant.

Causes of death by exposure category are shown in Table 4. No marked differences in specific causes of death are apparent between exposure categories. Cardiovascular diseases are most common, followed by various cancers. The proportionate mortality follows this pattern, with respiratory diseases in third place followed by suicides/accidents. This lack of differences is probably attributable to the relatively small numbers involved. Such a study should be replicated using larger populations, such as data from a number of companies or union records.

These results are consistent with those found in a mortality study of the general population (Ferris et al., 1971), in which no excess mortality was noted for the community as a whole where this plant was the major source of employment.

\section{MORBIDITY STUDY}

As noted above, 200 men were seen both in 1963 and 1973 . The morbidity study deals only with that population. From the responses to the questionnaire certain diagnoses were made. Chronic bronchitis was diagnosed if the subject admitted to producing phlegm twice or more daily on four or more days a week for three consecutive months of the year for the past three years. Asthma was diagnosed if the respondent had a history of bronchial asthma diagnosed by a physician, which condition was still present. Obstructive lung disease was diagnosed if the respondent admitted to a history of wheezing or 'whistling' in the chest on most days or nights, and/or shortness of breath that caused him to stop 
Table 5 Prevalence of chronic non-specific respiratory diseases in a pulp mill (a) 1963

\begin{tabular}{|c|c|c|c|c|c|c|}
\hline Age group (1963) & $\begin{array}{l}\text { No. of subjects } \\
\text { with disease }\end{array}$ & Chronic bronchitis & $\begin{array}{l}\text { Obstructive lung } \\
\text { disease }\end{array}$ & $\begin{array}{l}\text { Chronic bronchitis } \\
+ \text { obstructive lung } \\
\text { disease }\end{array}$ & $\begin{array}{l}\text { Bronchitis + obstruc- } \\
\text { tive lung disease } \\
\text { + asthma }\end{array}$ & Total \\
\hline $\begin{array}{l}25-34 \\
35-44 \\
45-54 \\
55-64 \\
65+\end{array}$ & $\begin{array}{c}7(87 \cdot 5)^{*} \\
26(74 \cdot 3) \\
19(76 \cdot 0) \\
24(63 \cdot 1) \\
3(100)\end{array}$ & $\begin{array}{c}1(12 \cdot 5) \\
5(14 \cdot 3) \\
3(12 \cdot 0) \\
11(28 \cdot 9) \\
0\end{array}$ & $\begin{array}{l}0 \\
1(2 \cdot 9) \\
1(4 \cdot 0) \\
0 \\
0\end{array}$ & $\begin{array}{l}0 \\
3(8 \cdot 6) \\
2(8 \cdot 0) \\
2(5 \cdot 3) \\
0\end{array}$ & $\begin{array}{l}0 \\
0 \\
0 \\
1(2 \cdot 6) \\
0\end{array}$ & $\begin{array}{r}8 \\
35 \\
25 \\
38 \\
3\end{array}$ \\
\hline All & $79(72 \cdot 5)$ & $20(18 \cdot 3)$ & $2(1 \cdot 8)$ & $7(6.4)$ & $1(0.9)$ & 109 \\
\hline
\end{tabular}

(b) 1973

\begin{tabular}{|c|c|c|c|c|c|c|}
\hline Age group (1963) & $\begin{array}{l}\text { No. of subjects } \\
\text { with disease }\end{array}$ & Chronic bronchitis & $\begin{array}{l}\text { Obstructive lung } \\
\text { disease }\end{array}$ & $\begin{array}{l}\text { Chronic bronchitis } \\
\text { + obstructive lung } \\
\text { disease }\end{array}$ & $\begin{array}{l}\text { Bronchitis + obstruc- } \\
\text { tive lung disease } \\
\text { + asthma }\end{array}$ & Total \\
\hline $\begin{array}{l}25-34 \\
35-44 \\
45-54 \\
55-64 \\
65+\end{array}$ & $\begin{array}{c}8(100)^{*} \\
28(80 \cdot 0) \\
17(68 \cdot 0) \\
21(55 \cdot 3) \\
3(100)\end{array}$ & $\begin{array}{l}0 \\
3(8 \cdot 6) \\
4(16 \cdot 0) \\
6(15 \cdot 8) \\
0\end{array}$ & $\begin{array}{l}0 \\
1(2 \cdot 8) \\
2(8 \cdot 0) \\
7(18 \cdot 4) \\
0\end{array}$ & $\begin{array}{l}0 \\
3(8 \cdot 6) \\
2(8 \cdot 0) \\
4(10 \cdot 5) \\
0\end{array}$ & $\begin{array}{l}\mathbf{0} \\
\mathbf{0} \\
\mathbf{0} \\
\mathbf{0} \\
\mathbf{0}\end{array}$ & $\begin{array}{r}8 \\
35 \\
25 \\
38 \\
3\end{array}$ \\
\hline All & $77(70 \cdot 6)$ & $13(11 \cdot 9)$ & $10(9 \cdot 2)$ & $9(8 \cdot 3)$ & 0 & 109 \\
\hline
\end{tabular}

* Percentages within age group in parentheses.

Table 6 Prevalence of chronic non-specific respiratory diseases in a paper mill (a) 1963

\begin{tabular}{|c|c|c|c|c|c|c|}
\hline Age group (1963) & $\begin{array}{l}\text { No. of subjects } \\
\text { with disease }\end{array}$ & Chronic bronchitis & $\begin{array}{l}\text { Obstructive lung } \\
\text { disease }\end{array}$ & $\begin{array}{l}\text { Chronic bronchitis } \\
\text { + obstructive lung } \\
\text { disease }\end{array}$ & $\begin{array}{l}\text { Bronchitis + obstruc- } \\
\text { tive lung disease } \\
+ \text { asthma }\end{array}$ & Total \\
\hline $\begin{array}{l}25-34 \\
35-44 \\
45-54 \\
55-64 \\
65+\end{array}$ & $\begin{array}{l}10(52 \cdot 6)^{*} \\
23(88 \cdot 5) \\
23(88 \cdot 5) \\
15(78.9) \\
0\end{array}$ & $\begin{array}{l}7(36 \cdot 8) \\
3(11 \cdot 5) \\
3(11 \cdot 5) \\
3(15 \cdot 8) \\
1(100)\end{array}$ & $\begin{array}{l}1(5 \cdot 3) \\
0 \\
0 \\
0 \\
0\end{array}$ & $\begin{array}{l}1(5 \cdot 3) \\
0 \\
0 \\
1(5 \cdot 3) \\
0\end{array}$ & $\begin{array}{l}\mathbf{0} \\
\mathbf{0} \\
\mathbf{0} \\
\mathbf{0} \\
\mathbf{0}\end{array}$ & $\begin{array}{r}19 \\
26 \\
26 \\
19 \\
1\end{array}$ \\
\hline All & $71(78 \cdot 0)$ & $17(18 \cdot 7)$ & $1(1 \cdot 1)$ & $2(2 \cdot 2)$ & 0 & 91 \\
\hline
\end{tabular}

(b) 1973

\begin{tabular}{|c|c|c|c|c|c|c|}
\hline Age group (1963) & $\begin{array}{l}\text { No. of subjects } \\
\text { with disease }\end{array}$ & Chronic bronchitis & $\begin{array}{l}\text { Obstructive lung } \\
\text { disease }\end{array}$ & $\begin{array}{l}\text { Chronic bronchitis } \\
\text { +obstructive lung } \\
\text { disease }\end{array}$ & $\begin{array}{l}\text { Bronchitis + obstruc- } \\
\text { tive lung disease } \\
\text { + asthma }\end{array}$ & Total \\
\hline $\begin{array}{l}25-34 \\
35-44 \\
45-54 \\
55-64 \\
65+\end{array}$ & $\begin{array}{c}10(52 \cdot 6)^{*} \\
20(76.9) \\
19(73.0) \\
13(68 \cdot 4) \\
1(100)\end{array}$ & $\begin{array}{l}5(26 \cdot 3) \\
4(15 \cdot 3) \\
1(3 \cdot 8) \\
3(15 \cdot 8) \\
0\end{array}$ & $\begin{array}{l}3(15 \cdot 8) \\
1(3 \cdot 8) \\
3(11 \cdot 5) \\
0 \\
0\end{array}$ & $\begin{array}{l}1(5 \cdot 3) \\
1(3 \cdot 8) \\
1(3 \cdot 8) \\
2(10 \cdot 5) \\
0\end{array}$ & $\begin{array}{l}0 \\
0 \\
2(7 \cdot 7) \\
1(5 \cdot 2) \\
0\end{array}$ & $\begin{array}{r}19 \\
26 \\
26 \\
19 \\
1\end{array}$ \\
\hline All & $63(69 \cdot 2)$ & $13(14 \cdot 3)$ & $7(7 \cdot 7)$ & $5(5 \cdot 5)$ & $3(3 \cdot 3)$ & 91 \\
\hline
\end{tabular}

* Percentages within age group in parentheses.

for breath when walking at his own pace on the level, and/or a mean $\mathrm{FEV}_{1.0}$ less than $60 \%$ of the FVC. As a group, these diagnoses are classified as non-specific respiratory disease.

The prevalence by age group of chronic nonspecific respiratory diseases in the pulp mill is shown in Tables 5a and 5b for 1963 and 1973 respectively, and similarly for the paper mill in
Tables $6 \mathrm{a}$ and $6 \mathrm{~b}$. There is considerable consistency in the rates between 1963 and 1973. If anything, the rates are lower in 1973 than in 1963. In addition, there seems little difference in the results for the pulp and the paper mill. The results presented in these tables have not been adjusted to take smoking into account, but smoking habits in the two groups were similar. We standardised for cigarette smoking 


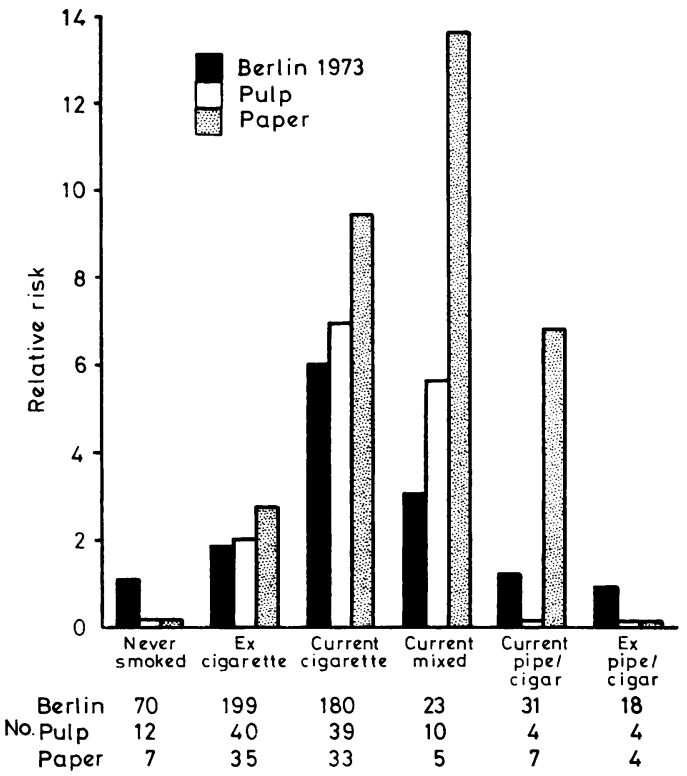

Fig. 1 Relative risk of developing chronic non-specific respiratory disease in a pulp mill and a paper mill compared with the general population of Berlin, by tobacco usage category.

by predicting the disease prevalence for the general population of Berlin, NH, from the 1973 data by cigarette smoking category. When these expected values from the general population were compared with the observed, no overall difference was noted between the pulp and the paper mill, and the general population.

In order to control for the effect of tobacco usage, the results were age-standardised by the indirect method:

Age-standardised rate for smoking category $=$ Observed $\times$ Crude rate for all smoking categories $\overline{\text { Expected }} \times$ together

These have then been expressed as a ratio of the observed over the expected rate using the rate in the male non-smoking population of Berlin in 1973 as the base, or 1.0. The results are presented in Figure 1 by tobacco usage and compared with similar data from the general population. There does not appear to be much difference within tobacco usage categories between workers in the pulp mill and the general population. There does appear to be an excess in the paper mill, however, especially for current mixed and pipe/cigar smokers.

A similar comparison using cigarettes smoked per day did not contribute additional information. It showed findings essentially similar to the results seen in 1963 (Ferris et al., 1967); namely, that the relative risk by cigarette smoking category was greater in the general population than in the working groups.

A more detailed analysis of positive responses to specific questions did not reveal any significant trends or differences. This may be because of the relatively small numbers or (which is more likely) to the insensitivity of the symptom prevalences per se.

The results of the tests of pulmonary function are presented for the various exposure categories in Figures 2-4. Figure 2 shows the results for the

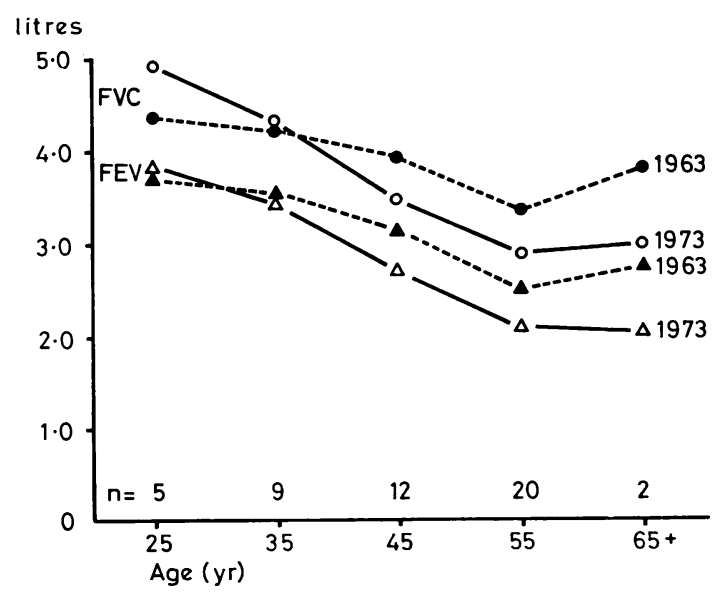

Fig. 2 Forced vital capacity (FVC) and one-second forced expiratory volume $\left(F E V_{1.0}\right)$ in men exposed to chlorine, by age categories. Results for 1963 (solid shapes) and 1973 (open shapes) are shown separately.

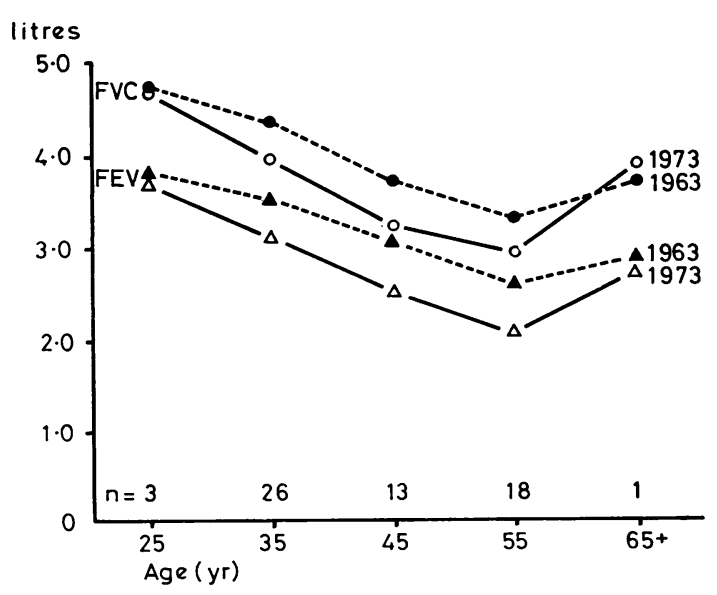

Fig. 3 Forced vital capacity (FVC) and one-second forced expiratory volume $\left(F E V{ }_{1.0}\right)$ in men exposed to $\mathrm{SO}_{2}$, by age categories. Results for 1963 (solid shapes) and 1973 (open shapes) are shown separately. 


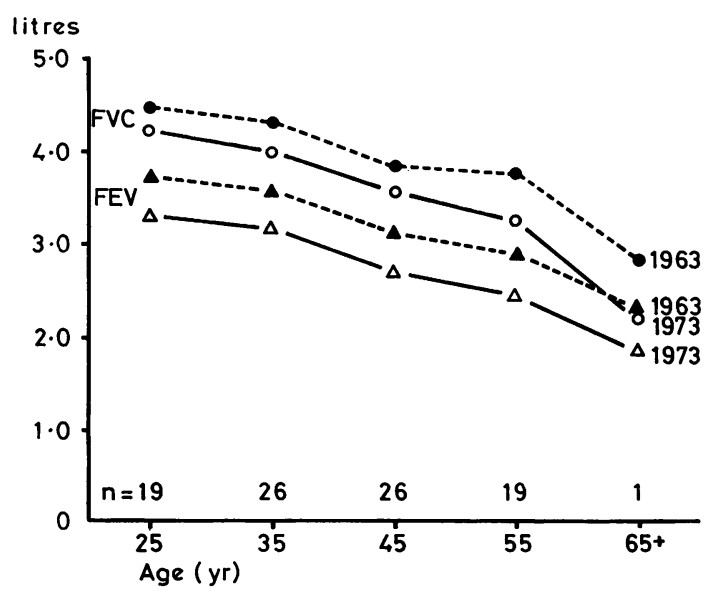

Fig. 4 Forced vital capacity (FVC) and one-second forced expiratory volume $\left(F E V_{1.0}\right)$ in men from the paper mill, by age categories. Results for 1963 (solid shapes) and 1973 (open shapes) are shown separately.

group exposed to chlorine, Figure 3, those exposed to $\mathrm{SO}_{2}$, and Figure 4, the results for paper workers. There is a decrease with age, which may be related in part to a decrease in the height of persons born earlier (a cohort effect). There is also some tendency for an increased change with age over the 10-yr period. This can also be seen in Table 7 and is similar to that reported by Fletcher et al. (1976) and Higgins et al. (1968) if the same group is followed over time. Some of the younger categories, as in the chlorine- and $\mathrm{SO}_{2}$-exposed groups, showed improvement or no change over the 10 years. This may be attributable to the small numbers in these groups or to our not having encouraged such complete expiration in 1963, or, as is more likely, to the fact that younger subjects change less and random variation can occur, so that an apparent increase is possible. The improvement in the oldest age group in the $\mathrm{SO}_{2}$-exposed category is based on only one subject and is contrary to what was seen in the other categories, where small numbers also existed. This is probably indicative of the variability of the measurements and illustrates that, even in the elderly, there may be individuals who show relatively little change with time. This was also noted by Fletcher et al. (1976).

There does not appear to be any difference in the mean change per year between the various exposure categories. If we ignore those groups that showed improvement, the values are quite comparable and consistent for each occupational category. These annual declines are also consistent with the annual decrements used in prediction formulae. For the 1967 Berlin male population these values were 38-39 $\mathrm{ml}$ per year for FVC and FEV 1.0 (see footnotes to Table 8).

We can also compare the predicted values calculated on both occasions. These are summarised in Table 8, where the pulmonary function in 1963 and 1973 are expressed as per cent predicted and averaged for the group. The prediction formulae from the 1973 Berlin male population are included. Values are still within the predicted range. It should be pointed out that these values, both observed and

Table 8 Pulmonary function in 1963 and 1973 expressed as percentage predicted ${ }^{*}$ by exposure categories (1963)

\begin{tabular}{|c|c|c|c|c|c|c|}
\hline \multirow[t]{2}{*}{ Year } & \multicolumn{2}{|c|}{ Chlorine } & \multicolumn{2}{|l|}{$\mathrm{SO}_{2}$} & \multicolumn{2}{|l|}{ Paper } \\
\hline & FVC & $F E V_{1 \cdot 0}$ & $F V C$ & $F E V_{1 \cdot 0}$ & $F V C$ & $F E V_{1 \cdot 0}$ \\
\hline $\begin{array}{l}1963 \\
1973\end{array}$ & $\begin{array}{l}100 \\
103\end{array}$ & $\begin{array}{l}101 \\
103\end{array}$ & $\begin{array}{l}101 \\
100\end{array}$ & $\begin{array}{l}102 \\
100\end{array}$ & $\begin{array}{l}101 \\
103\end{array}$ & $\begin{array}{l}104 \\
103\end{array}$ \\
\hline
\end{tabular}

*The prediction formulae used were based on Berlin 1967 male population.

Mean of last three of five trials (in general were also three best). FVC $(L)=0.04218 \mathrm{H}(\mathrm{cm})-0.0382 \mathrm{~A}(\mathrm{yr})-1.453(0.672$ standard error of the estimate).

FEV $_{1.0}(\mathrm{~L})=0.02819 \mathrm{H}(\mathrm{cm})-0.0386 \mathrm{~A}(\mathrm{yr})+0.097(0.584$ stan dard error of the estimate).

Table 7 Mean yearly change in pulmonary function 1963-1973 by exposure category and age group (1963)

\begin{tabular}{|c|c|c|c|c|c|c|}
\hline \multirow[t]{3}{*}{ Age group (1963) } & \multicolumn{6}{|c|}{ Exposure category (1963) } \\
\hline & \multicolumn{2}{|c|}{ Chlorine } & \multicolumn{2}{|l|}{$\mathrm{SO}_{2}$} & \multicolumn{2}{|l|}{ Paper } \\
\hline & $\overline{F V C}$ & $F E V_{1 \cdot 0}$ & FVC & $F E V_{1 \cdot 0}$ & FVC & $F E V_{1 \cdot 0}$ \\
\hline $\begin{array}{l}25-34 \\
35-44 \\
45-54 \\
55-64 \\
65+\end{array}$ & $\begin{array}{l}+45^{*} \\
+12 \\
-43 \\
-42 \\
-88\end{array}$ & $\begin{array}{l}+11 \\
-8 \\
-46 \\
-36 \\
-69\end{array}$ & $\begin{array}{l}-4 \\
-40 \\
-53 \\
-46 \\
+26\end{array}$ & $\begin{array}{l}-2 \\
-42 \\
-51 \\
-49 \\
-17\end{array}$ & $\begin{array}{l}-21 \\
-33 \\
-24 \\
-46 \\
-59\end{array}$ & $\begin{array}{l}-39 \\
-43 \\
-41 \\
-49 \\
-49\end{array}$ \\
\hline $\begin{array}{l}\text { Mean change } \\
\text { Mean change ignoring positives }\end{array}$ & $\begin{array}{l}-25 \\
-45\end{array}$ & $\begin{array}{l}-30 \\
-34\end{array}$ & $\begin{array}{l}-42 \\
-43\end{array}$ & $\begin{array}{l}-44 \\
-44\end{array}$ & $\begin{array}{l}-31 \\
-31\end{array}$ & $\begin{array}{l}-43 \\
-43\end{array}$ \\
\hline
\end{tabular}

$* \mathrm{ml} / \mathrm{yr}$.

For numbers in each age-exposure category, see Figs. 2-4. 
Table 9 Pulmonary function in retired, deceased, and working populations categorised by 1963 exposure category

\begin{tabular}{|c|c|c|c|c|c|c|c|c|}
\hline $\begin{array}{l}\text { Irritant } \\
\text { substance }\end{array}$ & $Y r$ & $\begin{array}{l}\text { Age } \\
(y r)\end{array}$ & $\begin{array}{l}\text { Height } \\
(\mathrm{cm})\end{array}$ & $\begin{array}{l}F V C \\
(l)\end{array}$ & $\begin{array}{l}\text { Observed minus predicted } \\
(l)\end{array}$ & $\begin{array}{l}F E V_{1 \cdot 0} \\
(l)\end{array}$ & $\begin{array}{l}F V C / F E V_{1 \cdot 0} \\
(\%)\end{array}$ & $\begin{array}{l}\text { Observed minus predicted } \\
(l)\end{array}$ \\
\hline \multicolumn{9}{|c|}{ Retired between 1963-73 } \\
\hline $\begin{array}{r}\mathrm{Cl}_{2} \\
(21)^{*} \\
\mathrm{SO}_{2} \\
(21) \\
\text { Paper } \\
(25)\end{array}$ & $\begin{array}{l}1963 \\
1973 \\
1963 \\
1973 \\
1963 \\
1973\end{array}$ & $\begin{array}{l}59 \cdot 0 \\
68 \cdot 8 \\
56 \cdot 8 \\
66 \cdot 31 \\
57 \cdot 0 \\
66 \cdot 7\end{array}$ & $\begin{array}{l}168 \cdot 0 \\
167 \cdot 3 \\
166 \cdot 4 \\
166 \cdot 1 \\
170 \cdot 9 \\
169 \cdot 9\end{array}$ & $\begin{array}{l}3 \cdot 28 \\
2 \cdot 88 \\
3 \cdot 32 \\
2 \cdot 91 \\
3 \cdot 78 \\
3 \cdot 36\end{array}$ & $\begin{array}{r}-0.100 \\
-0.090 \\
-0.073 \\
-0.112 \\
0.202 \\
0.193\end{array}$ & $\begin{array}{c}2.45 \\
2.09 \\
2.57 \\
2.09 \\
2.94 \\
2.46 \\
\text { mean } 1963: \\
\text { mean } 1973:\end{array}$ & $\begin{array}{l}75 \\
73 \\
77 \\
72 \\
78 \\
73 \\
76 \cdot 7 \\
72 \cdot 7\end{array}$ & $\begin{array}{r}-0.113 \\
-0.071 \\
-0.028 \\
-0.127 \\
0.228 \\
0.147\end{array}$ \\
\hline \multicolumn{9}{|c|}{ Deceased between 1963-73 } \\
\hline $\begin{array}{l}\mathrm{Cl}_{2} \\
\text { (9) }\end{array}$ & 1963 & $56 \cdot 6$ & $162 \cdot 8$ & $2 \cdot 71$ & -0.547 & 1.99 & 73 & -0.517 \\
\hline $\begin{array}{l}\mathrm{SO}_{2} \\
(8)\end{array}$ & 1963 & $54 \cdot 4$ & $171 \cdot 9$ & 3.65 & -0.068 & $2 \cdot 74$ & 75 & $-0 \cdot 101$ \\
\hline $\begin{array}{r}\text { Paper } \\
\text { (16) }\end{array}$ & 1963 & $48 \cdot 8$ & $173 \cdot 2$ & \multicolumn{5}{|c|}{ mean $74 \cdot 3$} \\
\hline \multicolumn{9}{|c|}{ Still working } \\
\hline $\begin{array}{r}\mathrm{Cl}_{2} \\
(27) \\
\mathrm{SO}_{2} \\
(40) \\
\text { Paper } \\
(66)\end{array}$ & $\begin{array}{l}1963 \\
1973 \\
1963 \\
1973 \\
1963 \\
1973\end{array}$ & $\begin{array}{l}43 \cdot 6 \\
53 \cdot 3 \\
42 \cdot 1 \\
51 \cdot 8 \\
40 \cdot 1 \\
49 \cdot 7\end{array}$ & $\begin{array}{l}171 \cdot 1 \\
170 \cdot 7 \\
171 \cdot 2 \\
170 \cdot 9 \\
172 \cdot 5 \\
172 \cdot 4\end{array}$ & $\begin{array}{l}4 \cdot 22 \\
3 \cdot 99 \\
4 \cdot 27 \\
3 \cdot 86 \\
4 \cdot 25 \\
3 \cdot 98\end{array}$ & $\begin{array}{r}0.013 \\
0.280 \\
0.110 \\
0.080 \\
-0.050 \\
0.060\end{array}$ & $\begin{array}{c}3.42 \\
3.09 \\
3.42 \\
3.00 \\
3.49 \\
3.08 \\
\text { mean 1963: } \\
\text { mean 1973: }\end{array}$ & $\begin{array}{l}81 \\
77 \\
80 \\
78 \\
82 \\
77 \\
81 \cdot 7 \\
77 \cdot 3\end{array}$ & $\begin{array}{l}0.180 \\
0.240 \\
0.120 \\
0.080 \\
0.075 \\
0.039\end{array}$ \\
\hline
\end{tabular}

* Number of subjects in category.

predicted, are based on the average of three readings, and will therefore be less than the highest reading. Because the percentage distribution by smoking categories was similar in the various groups, we have not corrected for this.

Similar analyses of the peak expiratory flow rates and the maximal expiratory flows at specific lung volumes did not provide additional information, Our earlier observation of a possible increase in smaller-airway disease, as shown by a greater concavity in men exposed to chlorine, could not be confirmed. This may be because of the small numbers in the older age groups, where this had been seen, or it may have reflected an acute response, as the men in 1963 were more heavily exposed than those exposed later. A further possibility is the variability of the measurement of flow-volume curves (Green et al., 1974). In addition, some of the men who had been classified as chlorine-exposed were no longer exposed; 26 of the 48 seen in 1963 had retired.

The possible effect of reduced exposure has been examined by looking at the men who had retired to see whether their levels of pulmonary function differed from those still working or those who had died. Table 9 shows the mean FVC and $F_{1.0}$ by exposure categories for retired, deceased, and still-working groups. The prediction formulae were the same as in Table 8 . Those retired workers who had been exposed to $\mathrm{Cl}_{2}$ and $\mathrm{SO}_{2}$ had slightly lower FVCs and $F V_{1.0}$ than the retired paper workers. These values have large standard deviations and so are not statistically significant. In addition, the differences in 1963 and 1973 are virtually the same, so there may be a cohort effect specific within each group. The deceased group showed a somewhat similar pattern with considerably larger differences in the chlorine group. It is of interest that the paper group died at a younger age than the men exposed to $\mathrm{Cl}_{2}$ or $\mathrm{SO}_{2}$. The men still working show a similar pattern to those who had retired, but tended to have larger FVC and $\mathrm{FEV}_{1.0}$ probably because of the differences in ages.

We have also separated the retired workers into two groups-those who had retired less than two years before 1973 and those who had been retired for more than two years. The two groups showed no differences in pulmonary function.

\section{Discussion and conclusions}

The question might be raised concerning the use of the general population as a basis against which to measure an effect in the men working in the mill.

Certainly the general population is more likely to contain subjects who are ill or disabled than is the working population. It also probably contains 
some who are more sensitive to irritants than those in the working environment. On the other hand, the general population is exposed to the pervading ambient levels of pollution and climate and should therefore reflect any resulting changes more clearly than some other population. They would also tend to have a comparable ethnic mix, differences in which could influence results. It was our conclusion that comparison with the general population, particularly using the non-smoking sector as the basis, was probably a reasonable approach. It was also possible within the working populations to examine differences between the different exposure categories, so that this, in a sense, was another sort of 'control' although, as pointed out earlier (Ferris et al., 1967), there had been some selfselection processes by the workers, so that those men remaining in the $\mathrm{SO}_{2}$ or $\mathrm{Cl}_{2}$ group were probably more tolerant of their working atmospheres than those in the paper mill.

With the various limitations noted above, we conclude that the men in the $\mathrm{Cl}_{2}$ or $\mathrm{SO}_{2}$ exposure categories did not suffer an increased mortality nor did there seem to be any increase in a particular specific cause of death. The pattern was consistent with that seen for the United States as a whole.

A 10-yr follow-up of 200 men with respect to respiratory symptoms and tests of pulmonary function showed no significant difference in the respiratory symptoms nor in the prevalence of chronic non-specific respiratory disease. The tests of pulmonary function (Table 9) suggest that chronic exposure to $\mathrm{Cl}_{2}$ and $\mathrm{SO}_{2}$ may have a slight adverse effect on FVC and FEV 1.0, compared with working in a paper mill. In the retired group, observed values were smaller than predicted, whereas no such differences were noted in those still working. In the deceased group the chlorine-exposed workers had lower observed than predicted values in 1963 whereas the values in the paper-worker group were actually higher than predicted. This could reflect an effect of earlier higher exposure to chlorine. This needs verification, however, by other studies on larger populations. These observations may reflect the relatively low current levels of exposure, and may also indicate that the earlier exposures had not produced significant disease.

The help and cooperation of Mr Robert Delisle, Health Officer for the City of Berlin, New Hampshire, USA is gratefully acknowledged. Mr Lawrence Dwyer, Superintendent of Schools, made facilities in the Junior High School available for interviews. The sample of the population from Berlin was most cooperative. Other members of the survey team were the Misses Mildred Allen, Patience Ferris, Betty Ann Sengstaken, and Mr Douglas Harper.

\section{References}

Ferris, B. G., Jr., Burgess, W. A., and Worcester, J. (1967). Prevalence of chronic respiratory disease in a pulp mill and a paper mill in the United States. British Journal of Industrial Medicine, 24, 26-37.

Ferris, B. G., Jr., Speizer, F. E., Worcester, J., and Chen, H. Y. (1971). Adult mortality in Berlin, NH from 1961 to 1967. Archives of Environmental Health, 23, 434-439.

Fletcher, C. M., Peto, R., Tinker, C., and Speizer, F. E. (1976). In The Natural History of Chronic Bronchitis and Emphysema, pp. 195-198; 244-246. Oxford University Press: London.

Green, M., Mead, J., and Turner, J. M. (1974). Variability of maximum expiratory flow-volume curves. Journal of Applied Physiology, 37, 67-74.

Higgins, I. T. T., Gilson, J. C., Ferris, B. G., Jr., Waters, M. E., Campbell, H., and Higgins, M. W. (1968). Chronic respiratory disease in an industrial town: a nine-year follow-up study. Preliminary report. American Journal of Public Health, 58, 1667-1676.

US Bureau of the Census (1971). Statistical Abstract of the United States, 92nd edition, Tables 71 and 72, pp. 54-55. US Department of Commerce: Washington, DC. 